\title{
Public health issues arising from microbiological and labelling quality of foods and supplements containing probiotic microorganisms
}

\author{
JMT Hamilton-Miller ${ }^{1, *}$, S Shah ${ }^{1}$ and JT Winkler ${ }^{2}$ \\ 'Department of Medical Microbiology, Royal Free and University College Medical School, London \\ NW3, UK: ${ }^{2}$ Food and Health Research, 28 St Paul Street, London N1, UK
}

Submitted 21 August 1998: Accepted 1 October 1998

\begin{abstract}
Objective: To assess the accuracy and helpfulness of labelling on products containing probiotic bacteria.

Design and setting: 52 such products - 44 from the UK (21 supplements, 15 fermented functional foods, eight 'health-care' products) and eight from continental Europe - have been tested for microbiological content, and results compared to the information available on their labels. Products were stored in the dark at $4^{\circ} \mathrm{C}$ and analysed before their expiry or sell-by date. Careful note was taken of wording on labels, package inserts, packaging, promotional literature and catalogue descriptions, as applicable. Products were cultured on appropriate bacteriological media, and organisms grown were counted and identified.

Results: Bioyoghurts gave no indication of numbers, and only five accurately described their bacterial content; results of culture were usually satisfactory. 'Healthcare' products (mostly intended for the bowel) usually indicated the presence of bacteria, but the numerical content was hard to ascertain, and cultural results fell short of label claims. Supplements were sometimes incorrectly labelled in bacteriological terms, and often contained markedly reduced numbers and/or had extraneous strains and/or strains specified on the label were missing. Products from continental Europe (that were sold for specific medical indications) seemed of a higher microbiological standard. The potential pathogen Enterococcus faecium was found in nine products. The most successful of the new functional foods in Britain now contain probiotics, and probiotic preparations are prominent among the expanding range of nutritional supplements presently available to consumers.

Conclusions: Our findings have public health implications, and suggest that improvements are needed in labelling and quality assurance procedures for products containing probiotic organisms. The presence of the potential pathogen Enterococcus faecium (intentionally or as a contaminant) in some products calls for a review of the value of this species as a probiotic.
\end{abstract}

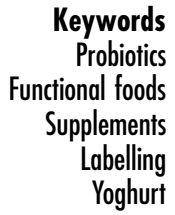

The concept that certain types of bacteria are 'friendly' as opposed to 'hostile' (i.e. promote health rather than disease) has been current for about 100 years ${ }^{1}$. Such 'friendly' bacteria are called 'probiotics' ${ }^{2}$. While there is some disagreement on scientific and commercial grounds over details of the precise meaning of this word $^{3}$, a reasonable working definition is 'preparations consisting of viable microorganisms and/or their components or metabolic products, that protect or otherwise benefit a host either directly or by augmenting natural physiological or defence mechanisms'.

Increased awareness of the potential benefits of a 'healthy' lifestyle has characterized the 1990s, and many foods and diet supplements have been launched purporting to be healthier. Thus, the so-called 'functional foods' contain added ingredients claiming to provide specific health benefits to consumers. The most successful of these products in Britain to date consist of, or contain, probiotics, and provide an early indication of some of the public health issues raised by the whole class of functional foods. At the same time, diet supplements have expanded beyond conventional vitamin and mineral pills to provide a wide range of novel compounds, including probiotics. The active 'functional ingredients' in both of these forms of probiotic products are the specific 'friendly' bacteria they contain, usually 'lactic acid bacteria', such as lactobacilli, enterococci, streptococci and bifidobacteria. 
Probiotics are available in the UK firstly, as supplements consisting of freeze-dried bacteria, secondly in fermented foods such as yoghurts, and thirdly in products aimed at enhancing specific aspects of 'health', such as bowel cleansers. In some countries probiotics are sold as remedies for specific medical conditions such as diarrhoea, a practice that is forbidden in the UK under the Medicines $\mathrm{Act}^{4}$.

Three public health issues are relevant to this group of products:

1. Are they safe, both on a personal and societal level? Our earlier work has drawn attention to the presence of Enterococcus faecium in several probiotic products $^{5}$, and questioned the risks involved in relation to possible benefits ${ }^{6}$.

2. Are they effective in fulfilling their promoted claims to enhance health? We $\mathrm{We}^{7}$ and others ${ }^{8,9}$ have concluded that this question remains open until proper clinical trials have been conducted.

3. Are they labelled clearly and accurately, so consumers may know precisely what they are buying? To be practically useful to consumers, labels should have the following information:

(a) notification of the presence of live bacteria;

(b) the precise nature of the bacteria;

(c) numbers of each species, in units comprehensible to consumers and microbiologically accurate;

(d) the minimum amount necessary to bring about any claimed health effect, either in terms of numbers of bacteria or of servings; and

(e) the accurate content at the time of purchase, not just at some stage during manufacture.

In order to investigate the problems set out above, we have undertaken a microbiological analysis of a wide range of various products containing probiotic bacteria, and correlated the results with information (or lack of it) on labels or associated promotional material.

\section{Materials and methods}

\section{Probiotic preparations}

A total of 52 preparations containing probiotic bacteria were investigated: 44 were purchased in the UK and eight preparations were obtained from other EU countries (three from France, two each from Denmark and Germany, one from Italy). All were products readily available to the ordinary consumer.

In the UK these products were:

- 21 different brands of supplements, most bought from retail pharmacies or health food shops, the remainder by mail order,

- 15 fermented functional foods (11 labelled as 'live' or 'bio' yoghurts, three fermented milks and one fromage frais), bought in supermarkets; and

- eight 'health-care' products labelled or described in catalogues as useful for a specific perceived problem (six to the bowel, one to candidiasis, one to the immune system). Most of these were from mail order catalogues.

The eight preparations obtained from other EU countries were capsules, tablets or suspensions indicated for gastrointestinal disorders, labelled as containing live microorganisms.

Products were stored in the dark at $4{ }^{\circ} \mathrm{C}$ and analysed before their expiry or sell-by date. Careful note was taken of wording on labels, package inserts, packaging, promotional literature and catalogue descriptions, as applicable.

\section{Microbiological methods}

Products were cultured on MRS agar (Unipath CM $359+1 \%$ agar), Fastidious Anaerobe agar (Lab M) supplemented with $5 \%$ whole horse blood (FAB) or $\mathrm{m}$-Enterococcus agar (Difco 0746-17), as appropriate. MRS agar is recommended by the International Dairy Federation ${ }^{10}$ for microbiological investigation of yoghurt. Plates were incubated at $37^{\circ} \mathrm{C}$ usually for $48 \mathrm{~h}$, MRS and FAB under anaerobic conditions (GasPak), m-Enterococcus agar in air. Bacteria were identified by colonial and microscopic morphology, susceptibility to metronidazole and reactions in the appropriate API kit.

Quantitative counts were made on products where a specific viable count was stated: a weighed amount of the product, suitably processed if necessary (i.e. a tablet was crushed in a sterile mortar, a capsule was opened), usually about $1 \mathrm{~g}$, was suspended in a measured volume of $0.1 \%$ Tryptone Soya broth (Unipath CM 129), vortexed and allowed to settle for $20 \mathrm{~min}$. Duplicate $0.1 \mathrm{ml}$ amounts of decimal dilutions of the supernatant fluid were spread onto plates, and colonies counted after incubation, as above. When products did not specify a particular viable count, qualitative investigations only were carried out.

\section{Results}

\section{Functional foods}

\section{Bioyoghurts (Table 1)}

Ten of the 11 products tested indicated that they contained live bacteria. Five accurately described the types of bacteria they contained, three by genus and species, using correct nomenclature, one by the term 'bifidus' (it contained Bifidobacterium sp.) and one citing LGG (= Lactobacillus sp. Goldin and Gorbach). The other five were less precise, their labels stating 
Table 1 Labelling and microbiological findings on 'live' or 'bio' yoghurts

\begin{tabular}{|c|c|c|}
\hline Product & Label & Finding \\
\hline 1 & $\begin{array}{l}\text { L. acidophilus } \\
\text { B. longum } \\
\text { S. thermophilus }\end{array}$ & $\begin{array}{l}\text { L. acidophilus } \\
\text { Bifidobacterium sp. } \\
\text { S. thermophilus }\end{array}$ \\
\hline II & 'Special bio-cultures' & $\begin{array}{l}\text { L. acidophilus } \\
\text { Bifidobacterium sp. }\end{array}$ \\
\hline III & 'Lactic acid culture' & $\begin{array}{l}\text { E. faecium } \\
\text { S. thermophilus }\end{array}$ \\
\hline IV & 'Active bifidus' & $\begin{array}{l}\text { Bifidobacterium adolescentis } \\
\text { Lactococcus lactis }\end{array}$ \\
\hline V & $\begin{array}{l}\text { L. acidophilus } \\
\text { S. thermophilus }\end{array}$ & $\begin{array}{l}\text { L. acidophilus } \\
\text { S. thermophilus }\end{array}$ \\
\hline VI & 'Live LGG culture' & $\begin{array}{l}\text { L. acidophilus } \\
\text { Lactobacillus sp.* }\end{array}$ \\
\hline VII & $\begin{array}{l}\text { L. bulgaricus } \\
\text { L. acidophilus } \\
\text { S. thermophilus } \\
\text { Bifidus Bifidum }\end{array}$ & $\begin{array}{l}\text { L. delbrueckii var. lactis } \\
\text { L. acidophilus } \\
\text { S. thermophilus } \\
\text { Bifidobacterium sp. }\end{array}$ \\
\hline VIII & 'Yoghurt culture' & $\begin{array}{l}\text { L. rhamnosus } \\
\text { L. delbreuckii var. bulgaricus } \\
\text { S. thermophilus }\end{array}$ \\
\hline IX & 'Selected cultures' & L. delbreuckii var. bulgaricus \\
\hline $\mathrm{x}$ & 'Special live cultures' & $\begin{array}{l}\text { L. acidophilus } \\
\text { S. thermophilus } \\
\text { Bifidobacterium sp. }\end{array}$ \\
\hline$X I$ & Bacteria not mentioned & $\begin{array}{l}\text { L. acidophilus } \\
\text { S. thermophilus } \\
\text { Bifidobacterium sp. }\end{array}$ \\
\hline
\end{tabular}

${ }^{*}$ Conforms to published description of Lactobacillus GG.

'lactic acid culture', 'yoghurt culture', 'special bioculture', 'special live culture', 'live yoghurt culture' and 'selected cultures'. The first of these contained E. faecium, the second L. rhamnosus and the others classic yoghurt organisms only, such as L. acidophilus, Streptococcus thermophilus and/or bifidobacteria. Only two of the 11 specified a particular strain (LC1 and GG), and two others used an adjective ('Causido', 'Biogarde') to describe an unspecified mixed culture.

The five products with precise labelling usually contained the species stated, and were free of extraneous bacteria, with two exceptions (the additional presence of, respectively, L. acidophilus and of Lactococcus lactis cremoris).

None of the 11 gave any indication of bacterial numbers.

\section{Other foods}

Two of the fermented milks identified a named bacterial strain (LC1, Shirota) on label or packaging. On culture, both contained the stated species. Numbers per millilitre were available for one species. The third product (a 'live cultured buttermilk') made no mention of a bacterial content; it was found to contain Lactococcus lactis.

The fromage frais was not labelled as containing bacteria, but $S$. thermophilus was isolated from it.

\section{'Health-care' products}

Results are summarized in Table 2. In six of the eight products tested the presence of bacteria was clearly identified on the label, and either L. acidophilus or bifidobacteria were specified. The other two were not clearly labelled as containing bacteria - one was stated to have 'super-prodophilus' (a term not instantly recognizable as referring to bacteria), and the other was stated in the catalogue but not on the label to contain 'intestinal flora'.

Numbers of viable bacteria were stated specifically on one product only, while two others quoted 'millions of viable organisms'. Four products labelled the bacterial content in milligrams only (reference to the catalogue allowed this to be translated into an actual number in two cases), and one gave no information on numbers.

Table 2 Labelling and microbiological findings on health-care products

\begin{tabular}{|c|c|c|c|c|}
\hline \multirow[b]{2}{*}{ Product } & \multicolumn{2}{|c|}{ Microbiological claims } & \multirow[b]{2}{*}{ Experimental findings } & \multirow[b]{2}{*}{ Comment } \\
\hline & Quantitative & Qualitative & & \\
\hline I & $10^{7}$ each & $\begin{array}{l}\text { L. acidophilus } \\
\text { L. bifidus }\end{array}$ & $2 \times 10^{4}$ L. acidophilus & Numbers low; one named species missing \\
\hline II & 'Millions' & L. acidophilus & $>10^{6}$ L. acidophilus & Satisfactory \\
\hline III & $\begin{array}{l}3 \mathrm{mg} \\
\text { (Catalogue: } 10^{10} \text { ) }\end{array}$ & L. acidophilus & $\begin{array}{l}3 \times 10^{4} L . \text { rhamnosus } \\
\text { small nos } E . \text { faecium }\end{array}$ & Low numbers; inadequate information on container \\
\hline IV & 'Millions' & L. acidophilus & $>10^{6}$ L. acidophilus & Satisfactory \\
\hline V & $300 \mathrm{mg}$ & L. acidophilus & No growth & Unsatisfactory; poorly labelled \\
\hline $\mathrm{VI}$ & $\begin{array}{l}\text { No information } \\
\text { (Catalogue: 'intestinal flora') }\end{array}$ & & No growth & Unsatisfactory; poorly labelled \\
\hline VII & $\begin{array}{l}5 \mathrm{mg} \\
\left(\text { Catalogue: } 10^{10}\right)\end{array}$ & Bifidobacterium & $2 \times 10^{7}$ lactobacilli & Low numbers; wrong species; poorly labelled \\
\hline VIII & $75 \mathrm{mg}$ & 'Superprodophilus' & $3 \times 10^{7}$ L. acidophilus & Labelling unhelpful qualitatively and quantitatively \\
\hline
\end{tabular}


Culture showed only two products to be satisfactory both qualitatively and quantitatively. Two failed to grow any bacteria, and four contained either lower than claimed numbers of the stated species, had extraneous species (E. faecium was isolated from one) or did not contain the stated species.

\section{Probiotic supplements}

\section{UK products (Table 3 )}

All 21 preparations tested were labelled as containing bacteria, but nomenclature was not always correct. For example, the term 'Lactobacillus bifidus' was used on four products; this name is over 20 years out of date, such strains having been transferred to the genus Bifidobacterium $^{11}$. However, we found that the species supplied to wholesalers under this name was in fact L. rhamnosus. E. faecium was labelled in three products by its former name of $S$. faecium (nomenclature was changed in 1984). Four products contained named strains of L. acidophilus (INT9, \#R and, in two products, DDS-1; however, in identification tests the two strains named as DDS-1 were found to differ by 10 characteristics, and thus cannot both be DDS-1). Nineteen products stated on the label the numbers of bacteria present; of the two that did not, one quoted milligrams only, and for the other the catalogue had to be consulted. For products that contained more than a single species, information on numbers was often confusing, a total count being given rather than individual counts of each species.

Microbiologically, seven products fulfilled their label claims quantitatively completely, and two more had counts within $50 \%$ of the on-label figure. In nine products counts were $90 \%$ or more below the stated figure (one product was sterile despite a label claim of $2 \times 10^{9}$ bacteria/tablet). No judgement could be made in the case of the product where a viable count had not been stated.

The 21 products tested contained, according to their labels, 47 bacterial species (20 L. acidophilus, 16 other lactobacilli, eight bifidobacteria, two E. faecium, one S. thermophilus). Only nine products contained only the species stated on the label; the other 12 either lacked one or more stated species, a species had been misidentified (e.g. L. rhamnosus in place of L. acidophilus), or there was a contaminant present (E. faecium or a pediococcus). The latter applied in five cases. Only seven of the 21 products tested were bacteriologically satisfactory both qualitatively and quantitatively.

\section{Non-UK products (Table 4)}

The eight products obtained from continental Europe and sold for medicinal purposes contained, according to the labels: three enterococci, one Escherichia coli, two Bacillus spp., one lactobacilli, one bifidobacteria and one Saccharomyces boulardii. All were labelled as containing microorganisms; all but one gave precise quantitation on label. One lacked one of the two species listed. All fulfilled their numerical claims.

\section{Discussion}

\section{Accurate naming of bacteria}

Certain bacterial strains have properties that suggest a potential probiotic activity in vivo?. However, not all strains of the same species will have these same abilities $^{12,13}$. Thus it is important that the consumer be able to select a product whose component bacteria have been shown to have useful properties; this is only possible if full information as to strain characterization is given on the label. Lactobacillus strains GG, La 1 (used to make LC1 products) and Shirota are examples of well-characterized strains on which much research has been done ${ }^{14-17}$. However, it cannot be assumed that the other (mostly anonymous) strains found here as 'probiotics' will also have similar beneficial properties.

Lay people aware of the potential of bifidobacteria as probiotics would probably assume (wrongly in this instance) that a product labelled ' $L$. bifidus' contained bifidobacteria - whereas in fact these strains were found to be L. rhamnosus. Furthermore, consumers knowing of 'superbugs' from the media might wish to avoid eating E. faecium, but be unaware that this species is present in several probiotic products, either as a contaminant, as the starter culture itself or masquerading under another name $(S$. faecium). As stated previously, we ${ }^{6}$ consider $E$. faecium to be more of a hazard than a benefit as a probiotic organism.

For these reasons it is important to the consumer, and should be incumbent upon the producer, to ensure that names of bacteria are correct and given in full. Inaccurate labelling also reflects badly on suppliers of probiotics (both the raw materials and finished product), having important negative implications for standards of quality control and scientific and manufacturing competence.

Consumers who buy probiotic supplements are actively looking for a source of potentially beneficial bacteria. However, in the case of purchases of yoghurt, the situation is not so clear cut. Yoghurt is a highly nutritious food ${ }^{18}$, and consumption in the UK has increased greatly during the 1990s, to an estimated $4.7 \mathrm{kghead}^{-1}$ in $1995^{19}$. Yoghurt is now a 'core' purchase $^{19}$, and is probably mostly bought as a convenient pleasant tasting snack or sweet rather than as a specifically recognized health food. Conversely, the increased sales of bioyoghurts, with their content of 'friendly' bacteria ${ }^{20,21}$, argues that here the consumer is, as for supplements, purposefully seeking 
Table 3 Labelling and microbiological findings on probiotic supplements bought in the UK

\begin{tabular}{|c|c|c|c|c|}
\hline \multirow[b]{2}{*}{ Product } & \multicolumn{2}{|c|}{ Microbiological claims* } & \multirow[b]{2}{*}{ Experimental findings ${ }^{*}$} & \multirow[b]{2}{*}{ Comment } \\
\hline & Qualitative & Quantitative & & \\
\hline A & $4 \times 10^{9}$ & $\begin{array}{l}\text { L. acidophilus } \\
\text { bifidobacteria }\end{array}$ & $\begin{array}{l}3.5 \times 10^{9} \text { L. acidophilus } \\
10^{7} \text { Bifidobacterium sp. }\end{array}$ & Satisfactory \\
\hline B & $2 \times 10^{9}$ & $\begin{array}{l}\text { L. acidophilus } \\
\text { L. bulgaricus }\end{array}$ & $<1$ bacterium & No bacterial growth \\
\hline C & $500 \mathrm{mg}$ & L. acidophilus & $\begin{array}{l}>10^{7} \text { L. acidophilus } \\
>10^{7} \text { L. fermentum } \\
10^{7} \text { Pediococcus sp. }\end{array}$ & Unhelpful quantitation, two extra species \\
\hline D & $2.5 \times 10^{8}$ & $\begin{array}{l}\text { L. acidophilus } \\
\text { B. bifidum }\end{array}$ & $\begin{array}{l}3 \times 10^{7} \text { L. acidophilus } \\
9 \times 10^{4} \text { L. plantarum } \\
5 \times 10^{4} \text { Pediococcus sp. }{ }^{\text {a }}\end{array}$ & Low count, two extra species; one named species missing \\
\hline $\mathrm{E}$ & $10^{8}$ & L. acidophilus & $\begin{array}{l}1.3 \times 10^{7} \text { L. delbrueckii } \\
5 \times 10^{3} \text { Enterococcus faecium }\end{array}$ & Named species missing, low numbers, extra species \\
\hline $\mathrm{F}$ & $10^{9}$ & L. acidophilus & $6.3 \times 10^{8}$ L. acidophilus & Acceptable \\
\hline G & $\begin{array}{l}>5 \times 10^{7} \\
>5 \times 10^{7}\end{array}$ & $\begin{array}{l}\text { L. acidophilus } \\
\text { L. bifidus }\end{array}$ & $\begin{array}{l}2.6 \times 10^{6} \mathrm{~L} \text {. fermentum } \\
10^{6} \mathrm{~L} \text {. rhamnosus } \\
10^{6}{\text { Pediococcus } \mathrm{sp} .^{a}} \\
1.6 \times 10^{3} \text { E. faecium }\end{array}$ & $\begin{array}{l}\text { Low numbers; named species missing; wrong nomenclature; } \\
\text { three extra species }\end{array}$ \\
\hline $\mathrm{H}$ & $4 \times 10^{9}$ & $\begin{array}{l}\text { L. acidophilus } \\
\text { B. bifidum }\end{array}$ & $\begin{array}{l}3 \times 10^{9} \text { L. acidophilus } \\
9 \times 10^{8} \text { Bifidobacterium sp. }\end{array}$ & Satisfactory \\
\hline I & $c 10^{9}$ & L. salivarius & $3 \times 10^{7}$ L. salivarius & Low numbers \\
\hline J & $4 \times 10^{9}$ & $\begin{array}{l}\text { L. acidophilus } \\
\text { bifidobacteria }\end{array}$ & $\begin{array}{l}3 \times 10^{9} \text { L. acidophilus } \\
2.5 \times 10^{8} \text { Bifidobacterium sp. }\end{array}$ & Satisfactory \\
\hline K & $>2 \times 10^{9}$ & $\begin{array}{l}\text { L. acidophilus } \\
\text { L. rhamnosus }\end{array}$ & $\begin{array}{l}1.2 \times 10^{6} \text { L. acidophilus } \\
1.4 \times 10^{4} \text { L. rhamnosus }\end{array}$ & Low numbers \\
\hline $\mathrm{L}$ & $2 \times 10^{9}$ & L. acidophilus & $2.2 \times 10^{9}$ L. acidophilus & Satisfactory \\
\hline M & $6.4 \times 10^{6}$ & L. acidophilus & $4 \times 10^{6}$ L. acidophilus & Acceptable \\
\hline$N$ & $8 \times 10^{9}$ & $\begin{array}{l}\text { L. acidophilus } \\
\text { L. rhamnosus } \\
\text { L. bifidus } \\
\text { S. faecium }\end{array}$ & $\begin{array}{l}3 \times 10^{7} \text { L. acidophilus } \\
7 \times 10^{6} \text { L. rhamnosus } \\
2 \times 10^{6} \text { L. rhamnosus } \\
7 \times 10^{8} \text { E. faecium }\end{array}$ & Low numbers; wrong nomenclature \\
\hline $\mathrm{O}$ & $4 \times 10^{9}$ & L. acidophilus & $5 \times 10^{9}$ L. acidophilus & Satisfactory \\
\hline$P$ & $2 \times 10^{9}$ & $\begin{array}{l}\text { L. acidophilus } \\
\text { L. rhamnosus } \\
\text { L. bifidus } \\
\text { S. faecium }\end{array}$ & $\begin{array}{l}3 \times 10^{7} \text { L. rhamnosus } \\
\quad \text { (two strains) } \\
7 \times 10^{8} \text { E. faecium }\end{array}$ & Named species missing; wrong nomenclature \\
\hline Q & $5 \times 10^{7}$ & Seven species ${ }^{b}$ & $9 \times 10^{5}$ six species & One named species missing; low numbers \\
\hline $\mathrm{R}$ & $2 \times 10^{9}$ & $\begin{array}{l}\text { L. acidophilus } \\
\text { L. rhamnosus } \\
\text { L. bifidus }\end{array}$ & $\begin{array}{l}2 \times 10^{8} \mathrm{~L} \text {. acidophilus } \\
2.6 \times 10^{9} \mathrm{~L} \text {. rhamnosus } \\
\quad \text { (two strains) }\end{array}$ & Numbers satisfactory; wrong nomenclature \\
\hline S & $2 \times 10^{7}$ each & $\begin{array}{l}\text { L. acidophilus } \\
\text { L. bulgaricus } \\
\text { B. bifidum }\end{array}$ & $\begin{array}{l}10^{6} \text { L. acidophilus } \\
5 \times 10^{4} \text { Bifidobacterium sp. }\end{array}$ & Low numbers; one named species missing \\
\hline $\mathrm{T}$ & $>10^{10}$ & L. acidophilus & $\begin{array}{l}1.1 \times 10^{10} \text { L. rhamnosus } \\
9 \times 10^{4} \text { E. faecium }\end{array}$ & $\begin{array}{l}\text { Numbers satisfactory; two extra species, and one named } \\
\text { species missing }\end{array}$ \\
\hline U & $10^{9}$ & Six species ${ }^{c}$ & $\begin{array}{l}2.2 \times 10^{6} \text { L. casei } \\
\text { small nos Pediococcus sp. }\end{array}$ & Numbers low; six named species missing; two extra species \\
\hline
\end{tabular}

${ }^{*}$ Per capsule, tablet or gram of powder, as appropriate.

${ }^{a} P$. pentosaceus.

${ }^{b} B$. breve, B. longum, S. thermophilus, L. rhamnosus, L. acidophilus, L. casei,

L. bulgaricus.

${ }^{c} L$. acidophilus, L. brevis, L. bulgaricus, L. causicus, L. salivarius, B. bifidum.

${ }^{\mathrm{d} P \text {. acidilactici. }}$ 
Table 4 Labelling and microbiological findings on probiotic products sold for medicinal purposes outside the UK

\begin{tabular}{|c|c|c|c|c|}
\hline \multirow[b]{2}{*}{ Product } & \multicolumn{2}{|c|}{ Microbiological claims } & \multirow[b]{2}{*}{ Experimental finding } & \multirow[b]{2}{*}{ Comment } \\
\hline & Quantitative & Qualitative & & \\
\hline$i$ & $\begin{array}{l}10^{7} \\
10^{7}\end{array}$ & $\begin{array}{l}\text { E. faecium } \\
\text { B. longum }\end{array}$ & $2.4 \times 10^{8}$ E. faecium & One named species missing \\
\hline ii & $10^{6}$ & S. faecium & $2 \times 10^{7}$ E. faecium & Wrong nomenclature \\
\hline iii & $1.5-4.5 \times 10^{7}$ & E. faecalis & $1.1 \times 10^{7}$ E. faecalis & Acceptable \\
\hline iv & $1.5-4.5 \times 10^{7}$ & Esch. coli & $6.7 \times 10^{6}$ Esch. coli & Acceptable \\
\hline $\mathrm{v}$ & $56.5 \mathrm{mg}$ & $\begin{array}{l}\text { Saccharomyces } \\
\text { boulardii }\end{array}$ & $2 \times 10^{7}$ S. cerevisiae ${ }^{a}$ & Acceptable; labelling unhelpful quantitatively \\
\hline vi & $8 \times 10^{8}$ & L. casei & $\begin{array}{l}1.2 \times 10^{9} \text { L. rhamnosus } \\
\text { (two strains) }\end{array}$ & One extra species \\
\hline vii & $10^{9}$ & Bacillus cereus & $9.7 \times 10^{8}$ Bacillus sp. & Acceptable \\
\hline ix & $10^{9}$ & Bacillus subtilis & $7 \times 10^{8}$ Bacillus sp. & Acceptable \\
\hline
\end{tabular}

${ }^{a} S$. boulardii has been reported to be an asporogenous form of $S$. cerevisiae.

probiotic bacteria. This further underscores the importance of accurate and helpful labelling of bioyoghurts.

\section{Importance of numbers}

Many of the products tested were not of a satisfactory standard quantitatively, and several (especially the yoghurts) could not be judged on this score because no target viable count was stated. This raises two important matters:

- Action against 'short measure' cannot be taken unless the manufacturers set a benchmark. Low viable counts may be present initially, suggesting inadequate quality control procedures, or may result from bacterial death during the period of shelf-life. In the case of supplements, which may have a shelflife of many months, improvements in freeze-drying techniques or the nature of excipients could have a beneficial effect on long-term viability.

- What constitutes a 'minimal effective dose' of a probiotic?

Despite much discussion on this point ${ }^{22}$, no doseresponse trials appear to have been carried out in humans. A daily dosage of $10^{6}$ to $10^{9}$ cells has been recommended ${ }^{9}$, apparently on an arbitrary basis. This is an unsatisfactory situation, but at least it gives the consumer some target at which to aim. There is great variability in the numbers of bacteria in bioyoghurts (unpublished results ${ }^{20,23}$ ), but for almost all the brands tested eating an average pot $(150 \mathrm{ml})$ would give the daily recommended dose. In the case of supplements, however, taking four tablets or capsules (a representative daily dose) would not necessarily supply $10^{9}$ bacteria (see Table 3). Clearly, those seeking the top end of the recommended probiotic range need accurate product information to enable them to do so. Giving bacterial content in terms of weight, although accurate in terms of the physical composition of capsules, tablets, powders, etc., is not helpful, as it is very difficult to convert dry weight into viable organisms.

\section{Conclusion}

It is clear from the above that labelling of probiotic products leaves much to be desired. With foods especially, the legal framework for labelling is underdeveloped. Neither the EU Nutrition Labelling Directive nor that on the Quantitative Declaration of Ingredients require the provision of any information on the probiotic bacteria in a product, nor indeed on any of the other new functional ingredients now coming onto the market. In this context, change can only occur through the good will of suppliers and manufacturers; attempts at moral persuasion have so far met with little or no success. In the absence of additional legal requirements on labelling there seems little hope for progress, and furthermore enforcement agencies are unable to act. We hope that this paper will act as a catalyst for change to better standards in this important field of nutrition. If consumers are to use label information to make healthy choices among products claiming to provide specific health benefits, then the general labelling principle should be that suppliers and manufacturers must declare the nature and amount(s) of the active ingredient(s) which produce the beneficial effects.

\section{References}

1 Bibel DJ. Elie Metchnikoff's bacillus of long life. ASM News 1988; 54: 661-5.

2 Parker RB. Probiotics, the other half of the antibiotic story. Animal Nutr. Health 1974; 29: 4-8.

3 Jansen GJ, Van der Waaij D. Review of the internal discussion. In: Fuller R, Heidt PJ, Rusch V, Van der Waaij D (eds) Probiotics; Prospects of Use in Opportunistic Infections Herborn-Dill: Institute for Microbiology and Biochemistry, 1995: 173-84. 
4 Medicines Control Agency. A Guide to What is a Medicinal Product (MAL 8). London: HMSO, 1995.

5 Hamilton-Miller JMT, Shah S, Smith CT. 'Probiotic' remedies are not what they seem. Br. Med.J. 1996; 312: 55-6.

6 Hamilton-Miller JMT, Shah S. Benefits and risks of Enteroccus faecium as a probiotic. In: Sadler MJ, Saltmarsh M (eds) Functional Foods: the Consumer, the Products and the Evidence. London: Royal Society of Chemistry, 1998: 20-4.

7 Hamilton-Miller JMT. Probiotics - panacea or nostrum? BNF Nutr. Bull. 1996; 21: 199-208.

8 Fuller R. Probiotics in human medicine. Gut 1991; 32 439-42.

9 Lee Y-K, Salminen S. The coming of age of probiotics. Trends in Food Sci. Technol. 1995; 6: 241-5.

10 International Dairy Federation. Yogurt. Enumeration of characteristic microorganisms. IDF Standard 117A. Brussels: IDF, 1988.

11 Buchanan RE, Gibbons NE (eds). Bergey's Manual of Determinative Bacteriology Baltimore: Williams \& Wilkins, 8th edn, 1974: 577.

12 Huis in't Veld JHJ, Shorrt C. Selection criteria for probiotic microorganisms. In: Leeds AR, Rowland IR (eds) Gut Flora and Health - Past, Present and Future. London: Royal Society of Medicine Congress and Symposium Series no. 219, 1996: 27-36.

13 Salminen S, Laine M, von Wright A et al. Development of selection criteria for probiotic strains to assess their potential in functional foods: a Nordic and European approach Biosci. Microfl. 1996; 15: 61-7.

14 Goldin BR, Gorbach SL. Probiotics for humans. In: Fuller R (ed) Probiotics: the Scientific Basis. London: Chapman \& Hall, 1992.

15 Richardson D. Probiotics and product innovation. Nutr. Food Sci. 1996; 4 (July/August); 27-33.

16 Salminen SJ, Saxelin M. Comparison of successful probiotic strains. Nutr. Today 1996; 31 (suppl.): 32S-34S.

17 Tanaka R. The effects of the ingestion of fermented milk with Lactobacillus casei Shirota on the gastrointestinal microbial ecology in healthy volunteers. In: Leeds AR, Rowland IR (eds) Gut Flora and Health - Past, Present and Future, London: Royal Society of Medicine International Congress and Symposium Series no. 219, 1996: 37-45.

18 Blanc B. The nutritional value of yoghurt. Int. J. Immunother. 1986; 11 (suppl.): 25-47.

19 Anon. Focus on yoghurt and fromage frais. The Grocer 1995; 217: 41-7.

20 Anon. Yoghurt: how healthy is it? Which 1993; April: 38-41.

21 Anon. Healthy eating: bioyoghurts. Health Which 1997; June: $92-5$.

22 Araneo BA, Cebra JJ, Beuth J et al. Problems and priorities for controlling opportunistic pathogens with new antimicrobial strategies; an overview of current literature. Zentralbl. Bakteriol. 1996; 283: 431-65.

23 Anon. Probiotics - the friendly bacteria. Health Which 1997; August: $134-5$. 